\title{
Influence of electric power and other forces on the quality of cotton seeds on the surface of working body
}

\author{
Parda Shoyimov, Bekhruz Murodov", Khudoyor Xafizov, and Barchinoy Murodova \\ Bukhara Engineering-Technological Institute, Bukhara, Uzbekistan
}

\begin{abstract}
The article covers the "Dielectric" device for sorting seeds of agricultural crops and results of theoretical research on seed sorting on this device. The results of theoretical experiments showed that the expected result could be achieved by applying a high voltage to the electrodes of opposite sign, the diameter of the working body of the device, and the number of turns to seed sorting in the "Dielectric" device.
\end{abstract}

\section{Introduction}

According to the information by the press service of the Ministry of Agriculture of the Republic of Uzbekistan, in 2020, cotton was grown on 1 million 34 thousand hectares of the republic, and 3 million 82 thousand tons of raw cotton received [1]. The main task is to process this grown raw cotton, provide the textile industry with quality fiber, and produce high-quality seeds for the 2021 harvest. Nowadays, of great economic and social importance is the processing and production of high-quality fiber from raw cotton, export products, production of oilseeds from seeds, and supply fodder for livestock development $[1,2]$.

\section{Methods}

It should be noted that every year an average of about 100 thousand tons of seeds are prepared for spring sowing and delivered to farmers for planting. At the enterprises of "Cluster" established in the country's regions, cottonseeds are sorted and prepared for sowing by using various equipment and devices [3].

Traditional seed processing technology involves the treatment of seeds prepared for sowing with drugs with different chemical compositions Seed preparation technology has been used for many years, but their performance efficiency is not very high. Because the chemicals used to treat the seeds are expensive, they pollute the soil and the environment to a certain extent [4].

The newly developed technology considers the physical-mechanical and biological properties of seeds enriched with various minerals, sorted by quality indicators, divided into two, i.e., seed and technical (waste) fractions [4].

\footnotetext{
*Corresponding author: behruzjonmurodov96@mail.ru
} 
The urgent problem in the newly established "Cluster" enterprises of the country is the compact, safe, metal, energy-saving, environmentally friendly, new innovative screening equipment and their application to the industry.

To find an effective solution to this problem, an industrial copy of the new innovative device "SDSE-2" based on the innovative "Electron-ion" technology, which has been created in collaboration with scientists of the Research Institute of Agricultural Mechanization and Bukhara Engineering-Technological Institute (BETI) under the leadership of Yusubaliev A. and Shoyimov P. has been developed [4-6].

This newly developed "SDSE-2" device allows sorting the seeds of agricultural crops according to their electrical resistance, electrical conductivity, dielectric constant, density, moisture, mass, and geometric dimensions while maintaining the physical, mechanical and biological properties [4].

This will increase the quality of seeds, sharply reduce planting costs, save metal and electricity costs, and increase the potential yield of raw cotton. This, in turn, leads to a reduction in the cost of the device. At present, these works are carried out at the "Cluster" enterprises by using pneumatic, geometrical, mechanical, aerodynamic methods of defining the density of seed mass [5].

Because the sorters, technologies, and technical means used in practice are not sufficiently developed, the sowing seeds do not fully meet the agro-technical requirements. The cost of sowing is $1.5 \div 2.0$ times higher than the scientifically based norm.

When preparing and processing this cottonseed for planting, the chemicals are used fall into the soil, causing a deterioration in the environmental situation. In the production of high-quality seeds that have biological properties close to each other and fully meet the above-mentioned agro-technical requirements, high yield, and potential yield in laboratory and field conditions, an electric sorter "Seed Dielectric Sorting Equipment" (SDSE-2) can be used to solve the problem mentioned above. The main advantages of this SDSE-2 device are as follows [5].

- High level of sorting accuracy;

- Low power consumption and metal use;

- Easy to prepare working body and device;

- Because of sorting, seeds are planted without treatment, soil and environmental purity are maintained;

- There will be no need for imported chemicals;

- Personnel safety is ensured during the technological process.

\section{Results and Discussion}

To implement the mentioned above actions, when seeds are selected in the "Seed Dielectric Sorting Equipment" (SDSE-2) device (Figure 1), developed jointly by scientists of the Research Institute of Agricultural Mechanization and Bukhara Engineering-Technological Institute, they germinate quickly in $5 \div 7$ days, potential yields increase in laboratory and field conditions, fiber content and quality improve, and average yield per hectare increases by $2.3 \div 4.6$ quintal/ha [5], and we have obtained and approved these results in field experiments. Also, less metal is used in the preparation of the working body of the device; it is easier to prepare, the cost of the device is reduced, electricity is saved, the device is universal, that is, if the diameter of the working body and electrodes changes the value of the high voltage applied to it, it is possible to sort the seeds of other crops in this device [59]. 


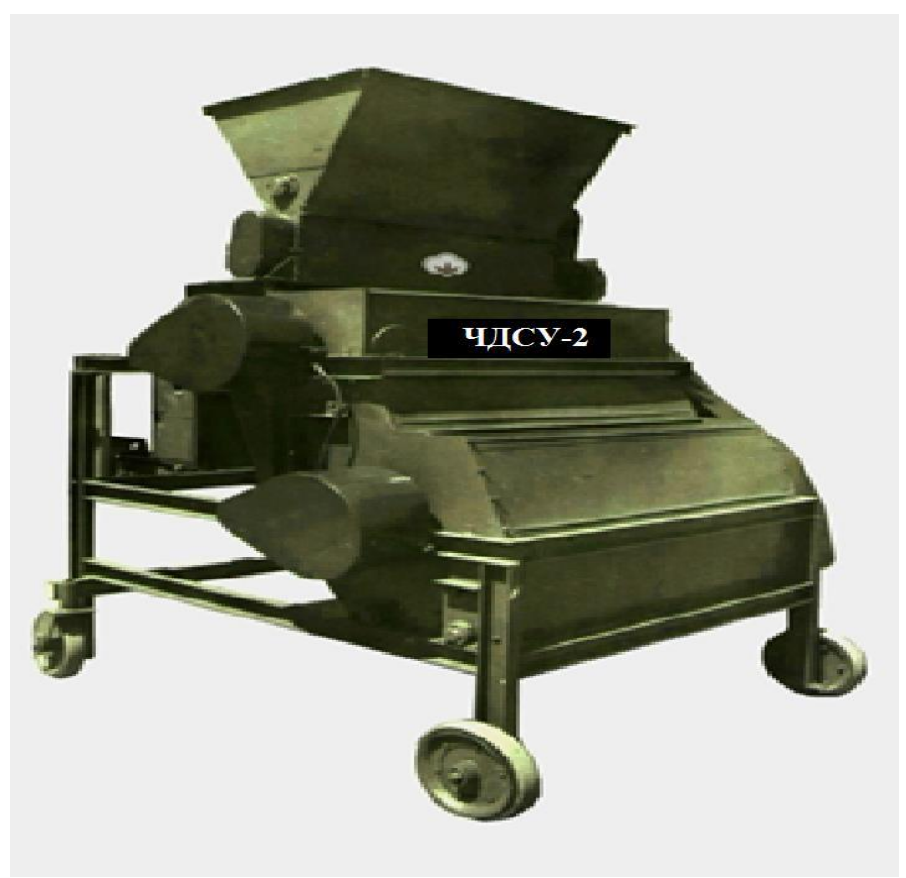

Fig. 1. General view of seed dielectric sorting equipment (SDSE-2).

Technical characteristics of seed dielectric sorting equipment (SDSE-2):

Work productivity

1. Fluffy seed

eed

(1)

2. Non-fluffy seed 4.0

3. Thin-fluff seed 6.0

4. Working voltage at the electrode 6.5

5. Total power received $2500-5500 \mathrm{~V}$

6. Number of working drums 4.4

2.0

7. Length of working drums, 1200

8 . The amount of seed separation suitable for sowing $85-95$ tons/hour Dimensions: ton ton ton

1. Height $\mathrm{m}$

2. Width 2.6

3. Length 2.1 1.8

4. Mass 1250

$\mathrm{kW}$

pcs

$\mathrm{mm}$ $\%$

$\mathrm{m}$

$\mathrm{m}$

$\mathrm{m}$

$\mathrm{kg}$

The device shows the forces acting on the cottonseed, which must be sorted by the technological process that takes place (Figure 2). 


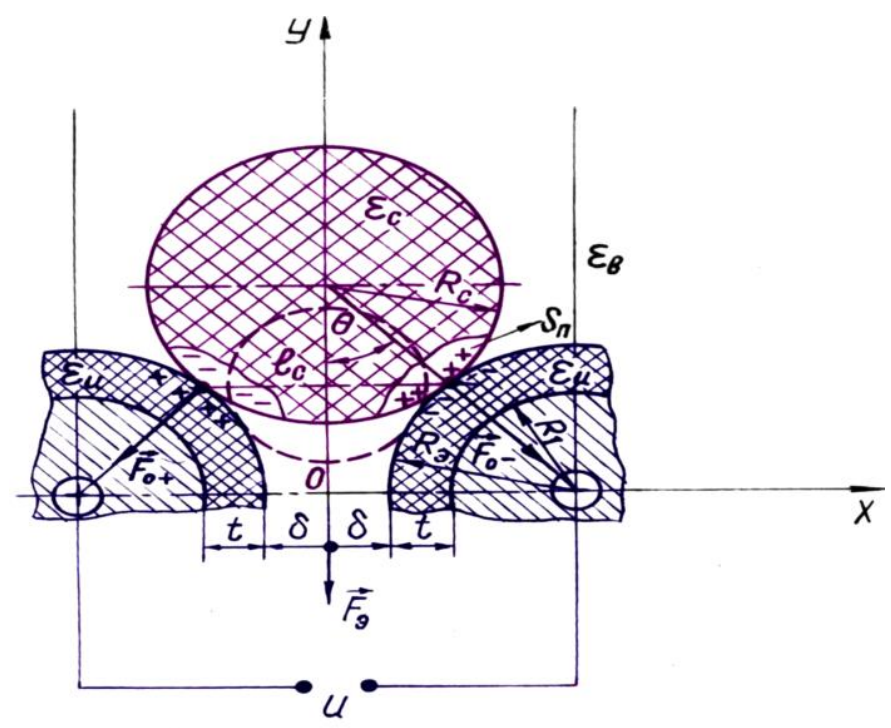

Fig. 2. Forces are acting on the seed between electrodes of different poles: $\delta$ is the distance between the electrodes; $\mathbf{t}$ is thickness of electrode protection; $R_{y}$ is the seed radius; $\varepsilon_{y}$ is dielectric saturation of seeds; $\theta$ is electric power and the angle between the vertical; $\mathbf{U}$ is constant voltage applied to electrodes; $F_{e l}^{+}+F_{e l}^{-}-$are positive and negative electric powers; $F_{e l}-$ is electric power

The operation of the device is as follows: the seed from the dock is delivered through the feeder to the surface of the rotating drum in a uniform sequence; the seed is dropped and charged between the different polar electrodes. Under the influence of the generated electric power is attracted to the electrodes on the surface of the working body, because of which the seed is divided into two fractions: seed and technical (waste) fraction [5].

As a result, fully ripened, large-sized, heavyweight seeds are divided into heavy fraction, unripe, empty, raw, small-sized seeds and weed seeds are divided into $2^{\text {nd }}$ fraction.

If we change the parameters of the working body of this device, the high voltage applied to the electrodes, the distance between the electrodes, the diameter of the electrode, it is possible to sort the other crops in this newly developed device SDSE-2 [4-6].

\section{Conclusions}

As an experiment, if we use the electrode made of polyvinyl chloride PC-75-4 on the surface of the rotating drum, when $E_{x}=4.0, R_{e}=36.5^{*} 10^{-3} \mathrm{~m}$ and $R_{l}=2.6^{*} 10^{-3} \mathrm{~m}$, U-voltage value is $2 \mathrm{kV}$, we observed that the weight does not reach the force. Hence, when the value of the voltage applied to the electrode is $2 \div 4 \mathrm{kV}$, we observed that the value of the electric power $F_{e l}$ is not equal to the weight, and we obtained the expected results.

We observed that it is possible to measure the electric power $F_{e l}$ when the value of the voltage applied to the electrodes is $U=2 \div 4 \mathrm{kV}[4,5]$. We observed these cases in the following graphs; that is, if we increase the voltage $U$ applied to the electrodes, we also observe that the electric power also increases [5-16]. 


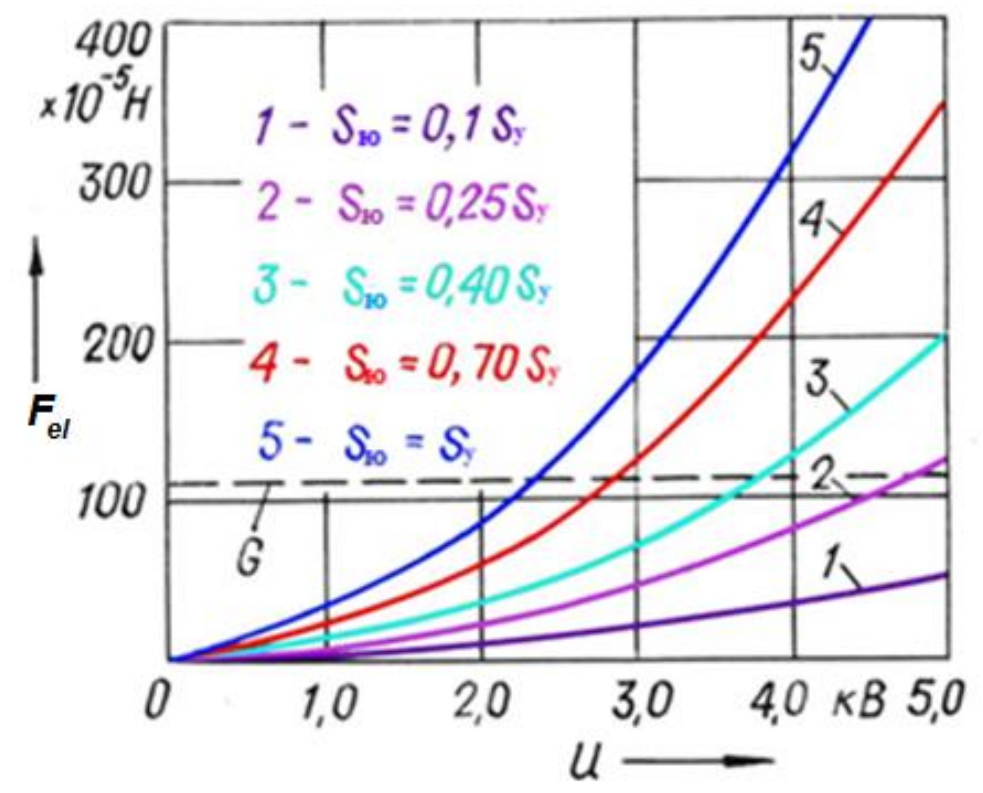

Fig. 3. The change in electrical power depending on the voltage of the electrodes at different levels of polarization of the seed: where $F_{e l}$ - is electric power; $U$ - is high voltage applied to the electrode, $S_{y u}$ is the polarizing surface of the seed, $S_{y}$ is surface of the seed, $\theta$ is the angle between the electric force and the vertical.

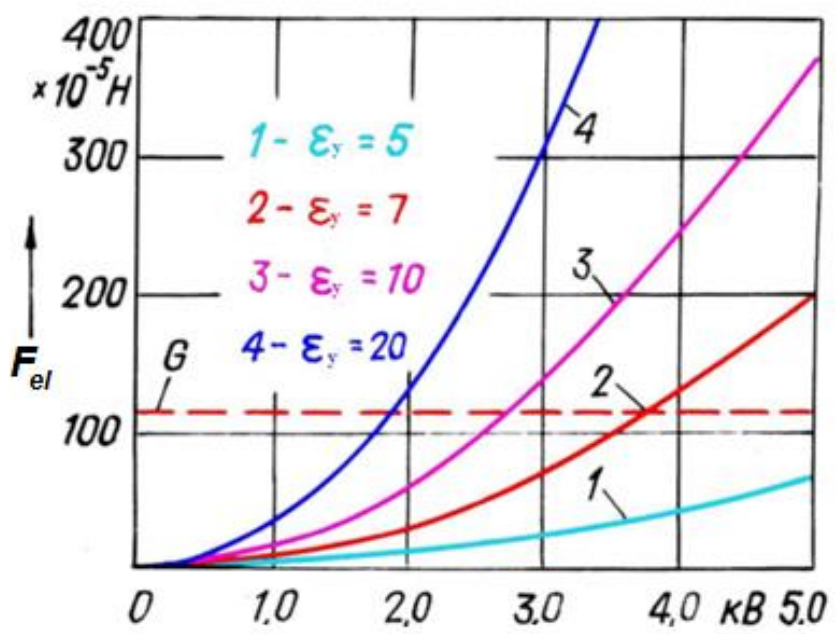

Fig. 4. The change in electrical power depending on the voltage of the electrodes at different dielectric constants of the seed: where, $F_{e l}$ - is electric power; $U$ - is high voltage applied to the electrode, $\varepsilon_{\mathrm{y}}$ is dielectric saturation of the seed, $G$ - is the angle between gravity and vertical. 


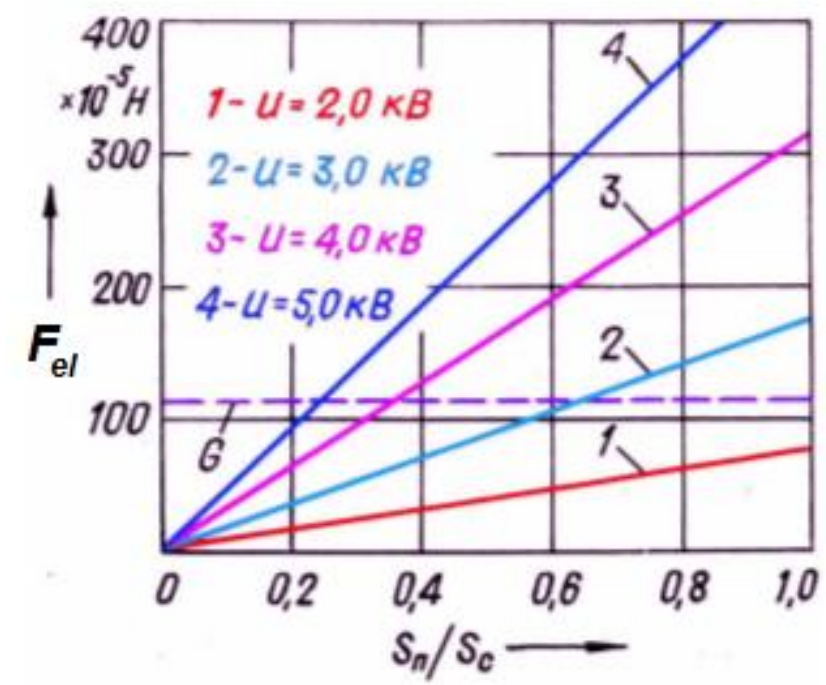

Fig. 5. The change in electrical power depending on the fraction of the polarized surface of the seed: where $F_{e l}-$ is electric power; $U-$ is high voltage applied to the electrode, $\theta-$ is the angle between the electric force and the vertical.

As can be seen from the graphs above, the value of the electric force has been shown to depend on the electric induction current at the surface of the capacitor, which is the surface of the seed.

As can be seen from graphs 3, 4, and 5, the relationship between electric power $F_{e l}$ and voltage $U$, the polarization surface of the seed shown in the graph in cases when $S_{y u}=0.1 S_{y}$, $S_{y u}=0.25 S_{y}, S_{y u}=0.40 S_{y}, S_{y u}=0.7 S_{y}$, and $S_{y u}=S_{y}$.

The next graph shows the relationship between electric force $\left(F_{y u}\right)$ and voltage (U), i.e., the case where the dielectric saturation of the seed is $\varepsilon_{\mathrm{y}}=5, \varepsilon_{\mathrm{y}}=7, \varepsilon_{\mathrm{y}}=10, \varepsilon_{\mathrm{y}}=20$.

The graph shows the connection between the electric power $\left(F_{e l}\right)$ and $\mathrm{S}_{\mathrm{yu}} / \mathrm{S}_{\mathrm{y}}$ in cases where the voltage applied to the electrodes, $U=2 \mathrm{kV}, U=3 \mathrm{kV}, U=4 \mathrm{kV}, U=5 \mathrm{kV}$.

From these graphs, it can be seen that the electric power $F_{\text {el }}$ and voltage $U$ applied to the electrode. We had found in the experiment that the polarization surface, dielectric constant, polarization surface, and voltage are the main determinants of the seed. The expected result was obtained when the sorting process was carried out in the "SDSE-2" device.

This, in turn, shows that the distance between the electrodes plays an important role in the electrical sorting of seeds of different geometric sizes; in particular, we obtained the following results when the equation is $2 b<\mathrm{V}$ when sorting cottonseeds in the SDSE-2 device [17-20].

We observed that the seed mass increased by $2 \div 4$ grams, the germination rate in the laboratory increased by $5 \div 6$ days, the germination rate in the field increased by $8 \div 10$ days, and the yield increased by 4.6 quintal/ha. Three variants of the newly developed technological scheme are shown. 
a)

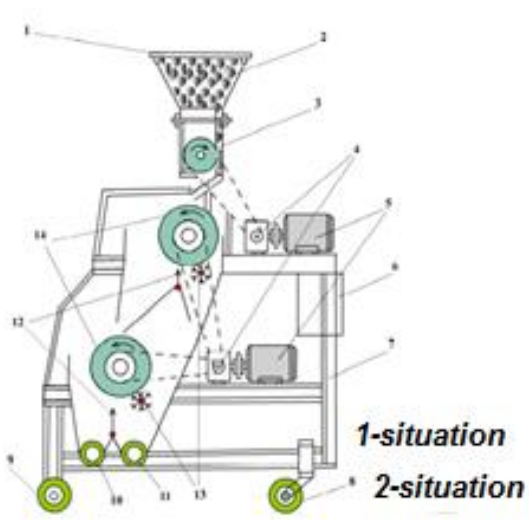

b)

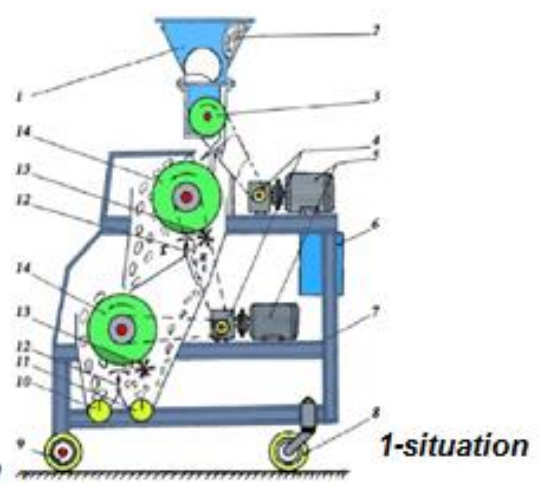

c)

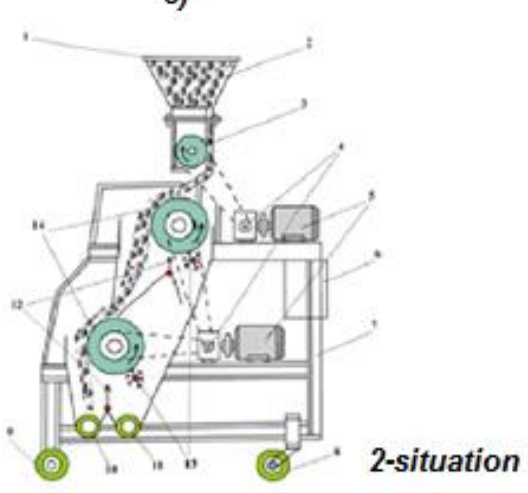

Fig. 6. Initial (a), with voltage (b) and without voltage (c) states of the seed dielectric sorting device (SDSE-2): 1 is bunker, 2 is cottonseed, 3 is supplier, 4 are reducers, 5 are electric motors, 6 is control shield, 7 is sorting device, 8 is rear wheel, 9 is front wheel, 10 is sawing seed screw, 11 is technical seed screw, 12 is separator, 13 is cleaning brush, 14 is working body.

In conclusion, we can say that we have established a direct relationship between the electric power $F_{e l}$ and the voltage $U$ applied to the electrodes.

\section{References}

1. Information service of the Ministry of Agriculture of the Republic of Uzbekistan, Tashkent, (2020)

2. National News Agency of the Republic of Uzbekistan, Tashkent, (2020)

3. Rakhimov H.R. More attention to the quality of killed seeds, Growing cotton, 4, pp. 910, (1980)

4. Yusubaliev A. Development of electric technological methods for the preparation of cottonseeds, Abstract of dissertation of doctor of technical sciences, Tashkent, p. 35, (2007)

5. Shoyimov P. Sorting of fluffy cottonseeds in a drum dielectric separator. Abstract of dissertation of candidate of technical sciences, Tashkent, p. 17, (1995) 
6. Yusubaliev A., Shoyimov P. Dielectric separator of cottonseeds, Proceedings of UzNSRIME, 34, pp. 15-154, (1992)

7. Khafizov I., Komil G., Oblokulov B., Azimov A. Elimination of energy losses in pumping installations by means variable frequency drive, International Engineering Journal For Research and Development, 5(3), E-ISSN NO: - 2349-0721, Impact factor: 6.03., pp.83-89, (2020)

8. Khafizov I., Komil G., Muxammedov Sh., Jurakulov A. Energy saving when using a variable frequency drive in pump installations, Journal of Critical Reviews, ISSN2394-5125, 7 (12), pp.99-102, (2020)

9. Khafizov I.I., Khaitov B.B. The investigation of ions implantation processes into a single-crystal GaAs (001) in order to increase the efficiency of the solar cells, MODERN SCIENCE International scientific journal № 02, 2017, Founder and publisher: "Strategic Studies Institute" LLC., pp.43-46, Moscow, (2017)

10. Khafizov I.I., Gafforov K.K. Application and prospects of variable frequency means in electric drives of pumping units, International scientific-practical electronic journal «MOYA PROFESSIONALNAYA KARERA» (ISSN 2658-7998, dogorov s Elibrary №284-07 / 2019), (2020)

11. Khafizov I.I., Khafizov X.I. Modeling the introduction of ions into single-crystal gaas (001) to create p-n junctions in order to increase the efficiency of solar cells, MOLODEJNYY ISSLEDOVATELSKIY POTENTSIAL, Sbornik statey II Mezhdunarodnogo nauchno-issledovatelskogo konkursa, sostoyavshegosya January 11. v g. Petrozavodsk, pp. 105-111

12. Amirov S.F., Babanazarova N.K., Research of dynamic operating mode of wide range current transformer, «European applied sciences». № 1, p. 52-54, Germany, (2016)

13. Amirov S.F., Babanazarova N.K. Magnetic circuit analysis of current transformer with multiple-turn core, «European applied sciences». № 7, pp. 23-26, Germany, (2016)

14. Amirov S.F., Rustamov D.Sh., Babanazarova N.K., Research of dynamic characteristics of electromagnetic current transducer, «European science review», № 3-4, pp. 95-98, Vienna, (2019)

15. Amirov S.F., Babanazarova N.K. Distantsionnye elektromagnitnye preobrazovateli bolshix peremennyx tokov. «UNIVERSUM», Scientific journal, 4 (73) Moscow, (2020)

16. Babanazarova N.K., Charyeva M.R. Voprosy preobrazovaniya bolshix peremennyx tokov. «UNIVERSUM», Scientific journal, 5 (75), Moscow, (2020)

17. Jumaboev S.X., Babanazarova N.K. Distantsionnyy elektromagnitnyy preobrazovatel bolshix tokov trexfaznyx vysokovoltnyx liniy, II Mezhdunarodnaya nauchnotehnicheskaya konferentsiya, posvyashchennaya 90- letiyu so dnya rojdeniya professora Zaripova Madiyara Fakhritdinovicha, pp. 131 -136, Russia, (2019)

18. Amirov S.F., Babanazarova N.K., Discrete Current Measuring Transformers, SHEMICAL TECHNOLOGY. CONTROL AND MANAGEMENT, International scientific and technical journal, 5-6 (95-96), pp.53-57, Tashkent, (2020)

19. Muzaffarov F. F., Jo'raev M. K., Rustamov S. Sh., Gafurov M. O., Raxmatova M. U., Badriddinov R. K. "On the distribution of mds and magnetic currents in the transformer" star-double zigzag with zero conduction "' XXV International ScientificPractical conference "EurasiaScience" PART I Research and Publishing Center "Actualnots.RF", Moscow, Russia, (2019)

20. Jo'raev M.Q, Muzaffarov F.F, Rustamov S.Sh. "Transparent Surface Lens Of LowTemperature Solar Devices" The American Journal of Applied Sciences, 2 (10), 145 149 